\title{
Spore germination, early development and some notes on the effects of in vitro culture medium on Frullania ericoides (Nees) Mont. (Frullaniaceae, Marchantiophyta)
}

\author{
Juliana da Costa Silva-e-Costa ${ }^{*}$, Andrea Pereira Luizi-Ponzo', Cristiano Ferrara de Resende ${ }^{1}$ \\ and Paulo Henrique Pereira Peixoto'
}

Received: September 10, 2016

Accepted: December 12, 2016

\begin{abstract}
In bryophytes, establishment can occur by a sexual or asexual process, but the production of spores enables colonization of a wider range of habitats and substrates than can asexual propagules. Successful germination is critical for establishment in a new environment. This paper addresses germination and sporeling development in Frullania ericoides, a leafy liverwort species. Fresh spores were inoculated in vitro in different culture strengths of Knop's nutrient solution (one-fourth strength, half strength, full strength, one and a half strength and double strength), in order to evaluate the effects of this solution on spore germination and on the development of external protonema. On the first assessment, spore germination was observed at all the concentrations. Germination was endosporic, with cell division and proliferation, resulting in a globular protonema, within the spore wall. Beginning at the fourth week, the development of tightly concave primordial leaves was observed in all but the double-strength medium. Throughout the period of study, the treatments with lower concentrations exhibited external protonema with greater lengths. The double-strength treatment was statistically different from other treatments in at least two parameters. The results of this study demonstrate the potential of in vitro culture techniques for bryophyte spore studies and germplasm preservation.
\end{abstract}

Keywords: endosporic development, Knop's medium, liverworts, nutrients, protonema, sporeling

\section{Introduction}

Bryophytes are non-lignified cryptogamic plants that have a life cycle with alternating heteromorphic generations in which the gametophyte is the dominant phase (Gradstein et al. 2001; Gradstein \& Costa 2003; Goffinet et al. 2009; Vanderpoorten \& Goffinet 2009). This plant group presents three monophyletic lineages: mosses, liverworts and hornworts (Goffinet et al. 2009); and the main differences that separate these lineages are: gametophyte structure (leafy or talose), leaves morphology (e.g. shape, size, trigones, oil bodies, costa, papillae), and sporophyte features (e.g. parts, sporogenesis, maturation) (Gradstein et al. 2001).

In bryophytes, dispersal, colonization and new plant development can proceed through spore production and germination (sexual reproduction) or through vegetative diaspores or fragmentation (asexual reproduction) (Nehira 1983; Schofield 1985; Gradstein et al. 2001; Wiklund \& Rydin 2004). Once the gametophyte reaches sexual maturity,

\footnotetext{
${ }^{1}$ Departamento de Botânica, Instituto de Ciências Biológicas, Universidade Federal de Juiz de Fora, 36036-900, Juiz de Fora, MG, Brazil

* Corresponding author: julcsilva@gmail.com
} 
and the environmental conditions are favourable, male and female multicellular gametangia are formed, antheridia and archegonia respectively. In the presence of water, a motile antherozoid reaches the egg cell, and from fertilization and zygote formation (sexual reproduction) begins the sporophytic phase (Goffinet et al. 2009; Vanderpoorten \& Goffinet 2009). The sporophyte, although perennial, is responsible for the production of spores, which are considered the first cell of gametophytic stage (Schofield 1985). This reproduction by producing spores enables the colonization of new substrates through dispersal mainly by wind (Zanten \& Pócs 1981; Longton \& Schuster 1983; Wiklund \& Rydin 2004; Longton 2006; Glime 2007). In order for establishment in a new environment to be effective, a successful spore germination processes is fundamental (Glime 2007).

In bryophytes, spore germination is initiated with swelling, resulted from water absorption by the spore; and distension, when the protonema formed ruptures the cell wall (Nehira 1983; Crandall-Stotler et al. 2009; Glime 2015). There are two patterns of spore germination: endosporic and exosporic (Neidhart 1979; Nehira 1983; Glime 2015). In endosporic germination, the spore protoplast divides within the spore wall, forming a multicellular structure. The protonema develops inside the stretched spore wall. In exosporic pattern, in the early stages of germination, the swollen protoplast ruptures the spore wall and the development of a protonema occurs outside (Nehira 1983; Schofield 1985; Nehira 1987; Goffinet et al. 2009; Glime 2015). The kind of germination process can be related to the ecological adaptation of plants; endosporic germination commonly occurs in some epiphytic and saxicolous taxa, whereas exosporic germination occurs in wet habitat species (Nehira 1987).

Many studies exist related to the germination of bryophyte spores, their stages of development and the factors influencing their success, as water and light availability, type of substrate, seasonality, among others, has been developed especially for mosses and liverworts (Inoue 1960; Vallane 1966; 1971; Udar \& Srivastava 1970; Mogensen 1978; 1983; Olesen \& Mogensen 1978; Brown \& Lemmon 1988; Alcade et al. 1996; McLetchie 2001; Wiklund \& Rydin 2004; Zhao et al. 2004; Maciel-Silva et al. 2009a; b; Alfayate et al. 2013). Vallane (1966; 1971) studied the germination of spores of Ceratodon purpureus. Olesen \& Mogensen (1978) studied the ultrastructure and histochemistry on germination of mosses Ceratodon purpureus, Funaria hygrometrica, Macromitrium sulcatum and Polytrichum commune, emphasizing the analysis in electron microscopy. Nehira (1983) described and detailed the types of development of protonema of mosses and liverworts. Wiklund \& Rydin (2004) studied two mosses species regarding physiological features to spore establishment, and Zhao et al. (2004) observed the characteristics of spore germination in Lindenbergia brachyptera. Maciel-Silva et al. (2009a; b) studied the effects of water availability and light spore germination of the mosses Octoblepharum albidum and Thamniopsis incurva, taxa well represented in Brazilian bryoflora. For liverworts, the works of Inoue (1960), Fulford (1956) and Nehira (1966) were notable by the fact that they were the first report about sporeling development in this group.

Frullaniaceae (Marchantiophyta) is a family of leafy liverworts characterized by creeping plants, median to robust, forming branched tufts, usually epiphytic in habit. The leaves are incubous, with usually inflated lobes, often transformed into water sacs, and the stylus is multiform (Stotler 1970; Yuzawa 1991; Lemos-Michel 2001; Gradstein \& Costa 2003; Uribe \& Gradstein 2003; Uribe 2008; Crandall-Stotler et al. 2009; Hentschel et al. 2009; Konrat et al. 2012). This family is distributed worldwide, achieving greater richness and diversity in tropical regions (Gradstein et al. 2001). Frullaniaceae spores are large and brownish and some species show precocious and endosporic germination (Heckman 1970; Crandall-Stotler et al. 2009).

Frullania ericoides stands out by virtue of its widespreading and squarrose leaves on the dorsal surface, laminate or saccate lobes and rough perianth (Oliveirae-Silva \& Yano 2000; Lemos-Michel 2001; Gradstein \& Costa 2003; Yano \& Peralta 2008). As in many other family members, this species presents tropical and subtropical distribution (Berghen 1976). In Brazil, it is found in all regions of the country (Peralta 2015). It can be found colonizing living and dead tree trunks and growing on rock (Yuzawa 1991; Lemos-Michel 2001; Gradstein \& Costa 2003; Paiva et al. 2015; Peralta 2015). Berghen (1976) and Gradstein \& Pócs (1989) observed that F. ericoides is easily found in places where the vegetation has gone through degradation processes and in urban areas.

Although already exist some studies related to spore morphology and studies of sporoderm in Frullaniaceae (Erdtman 1957; Schuster 1966; Heckman 1970; Gupta \& Udar 1986; Zhang \& Wu 2006; Wu et al. 2008; Zhao et al. 2011), researches related to spore germination are scarce, especially those that assess the effect of culture medium on the development of protonema. Nehira (1983) studied and described the sporeling development of eight species of Frullania genus, and report the Frullania-Type development of protonema in several taxa and families. Bisang (1987), in turn, studied sporeling morphology and development in Frullania tamarisci. The nutritive medium of Knop has been used in several works of bryophytes physiology (Horikawa \& Nehira 1960; Udar \& Srivastava 1970; Nehira 1988; Alcade et al. 1996; Duckett et al. 2004; Chen et al. 2009; Maciel-Silva et al. 2009a; b; Awasthi et al. 2012; Alfayate et al. 2013; Sahu \& Asthana 2013; Krishnan \& Murugan 2014; among others), including using diluted concentrations. However, none of these studies evaluate if the dilution or concentration of nutrients recommended affects the development of protonema; the attention is directed to the use of different culture media. 
In view of the wide distribution of the species F. ericoides, ecological features and the scarcity of palynological and physiological studies concerning this species; and further the lack of studies to evaluate different concentrations of the same culture medium, our work aims to (1) describe the spore germination morphology, detailing phases of in vitro protonema development of Frullania ericoides and (2) evaluate the response of growth on different strength of culture media, based on a medium already used in the literature.

\section{Materials and methods}

\section{Sample collection and identification}

We collected specimens of Frullania ericoides (Nees) Mont. in the Botanical Garden of the Universidade Federal de Juiz de Fora (UFJF), Minas Gerais state, Brazil, following the method for bryophytes (Yano 1989), using a knife to remove samples of bark of vascular plants (phorophytes) and storing the material collected in paper bags.

In the Bryophytes Laboratory of the Universidade Federal de Juiz de Fora, the plants were observed under a stereoscopic and light microscope with forceps and stiletts, referring to specialized literature for their identification (Lemos-Michel 2001; Gradstein \& Costa 2003; Uribe \& Gradstein 2003; Uribe 2008). After that, samples were dried in shade and mature capsules were separated for the study of germination, placed in Eppendorf tubes. Specimens were deposited in the collection of Herbarium Leopoldo Krieger (CESJ), Universidade Federal de Juiz de Fora.

\section{Sterilization}

Mature capsules were placed in capped glass vessels and washed with freshly prepared $1.5 \%$ solution of sodium hypochlorite and washed in tap water for $3 \mathrm{~min}$. Following this, the capsules were washed in sterile distilled water (Duckett et al. 2004). The surface disinfection process was undertaken in a laminar flow hood $\left(\operatorname{Veco}^{\circledR}\right)$.

\section{Preparing culture medium}

For this study, Knop nutrient solution following the modifications proposed by Nehira (1988) $\left[0.5 \mathrm{~g} \mathrm{~L}^{-1} \mathrm{Ca}\left(\mathrm{NO}_{3}\right)_{2}\right.$.
$\mathrm{H}_{2} \mathrm{O} ; 0.175 \mathrm{~g} \mathrm{~L}^{-1} \mathrm{MgSO}_{4} .7 \mathrm{H}_{2} 0 ; 0.175 \mathrm{~g} \mathrm{~L}^{-1} \mathrm{KH}_{2} \mathrm{PO}_{4} ; 0.06 \mathrm{~g}$ $\mathrm{L}^{-1} \mathrm{KCl}$; one drop of $\left.\mathrm{FeCl}_{3}(3 \%)\right]$ was used in five different concentrations. To facilitate the preparation to the assay, the following stock solutions were prepared: $\mathrm{A}: \mathrm{Ca}\left(\mathrm{NO}_{3}\right)_{2} \cdot 4 \mathrm{H}_{2} \mathrm{O}$ - (7.1957 g/100 mL), $10 \mathrm{~mL} / \mathrm{L} . \mathrm{B}: \mathrm{MgSO}_{4} \cdot 7 \mathrm{H}_{2} \mathrm{O}-(1.75$ $\mathrm{g} / 100 \mathrm{~mL}), 10 \mathrm{~mL} / \mathrm{L}+\mathrm{KH}_{2} \mathrm{PO}_{4}-(1.75 \mathrm{~g} / 100 \mathrm{~mL}), 10 \mathrm{~mL} / \mathrm{L}$ $+\mathrm{KCl}-(0.6 \mathrm{~g} / 100 \mathrm{~mL}), 10 \mathrm{~mL} / \mathrm{L} . \mathrm{C}: \mathrm{FeCl}_{3} \cdot 6 \mathrm{H}_{2} \mathrm{O}-(0.39985$ $\mathrm{g} / 25 \mathrm{~mL}), 4$ drops/L.

To prepare $100 \mathrm{~mL}$ of different media, stock solutions were added as described in Tab. 1. Media were jellified with agar at $0.4 \mathrm{~g} / 100 \mathrm{~mL}$ (Maciel-Silva et al. 2009a) and $\mathrm{pH}$ was adjusted to $5.6 \pm 0.1$ (George et al. 2008). The culture medium was autoclaved for $20 \mathrm{~min}$ at $120^{\circ} \mathrm{C}$ and a pressure of $1 \mathrm{~atm}$ (George 2008).

\section{Inoculation and culture conditions}

Test tubes with $1.5 \mathrm{~cm}$ diameter, $10 \mathrm{~cm}$ in height and a capacity of $15 \mathrm{ml}$ were used and to each we added $4 \mathrm{ml}$ of the different strengths of nutrient solution. For each treatment, we prepared 25 tubes. For the monitoring experiment, it was established that one tube of each treatment would be analysed on each day of observation. The use of test tubes makes more objective the protocol of material observation; turn this methodology more efficient and less susceptible to contamination.

After the material was observed, this tube was discarded to eliminate the risk of contamination. Duckett et al. (2004) recommend the use of fresh, recently collected material in germination studies. After the disinfection procedures, the capsules were transferred to sterile Petri dishes and taken to stereoscopic microscopy to be opened with the aid of forceps sterilized and a scalpel in a longitudinal cut. Then, using stylets, the spores were gently removed from the inside of the capsule and inoculated in the culture medium. In each test tube about ten spores were inoculated. Immediately after inoculation, the tubes were sealed with aluminium foil and PVC film.

After the in vitro inoculation, the tubes were kept in a growing room at $24 \pm 3^{\circ} \mathrm{C}$, under $40 \mathrm{~W}$ fluorescent lamps cool-white and Gro-Lux (Sylvania, Danvers, MA, USA), at a 1:1 ratio - with a photon flux density of $45 \mu$ moles of photons $\mathrm{m}^{-2} \mathrm{~s}^{-1}$ at $16 / 8 \mathrm{~h}$ photoperiod. Assay tubes were inspected daily for any symptoms of fungal or bacterial contamination. The tubes were rotated into growing room to equalize the possible temperature fluctuations.

Table 1. Preparing of culture media at different concentrations by using the stock solutions.

\begin{tabular}{|l|c|c|c|}
\hline \multicolumn{1}{|c|}{ Treatments } & Stock A & Stock B & Stock C \\
\hline One-fourth strengh: Medium $\mathbf{0 . 2 5 ~ S}$ & $0.25 \mathrm{~mL}$ & $0.25 \mathrm{~mL}$ & $1 \mathrm{drop}$ \\
\hline Half strengh: Medium $\mathbf{0 . 5 ~ S}$ & $0.5 \mathrm{~mL}$ & $0.5 \mathrm{~mL}$ & 2 drops \\
\hline Full strengh: Medium $\mathbf{1 ~ S}$ & $1 \mathrm{~mL}$ & $1 \mathrm{~mL}$ & 4 drops \\
\hline One and a half strength: Medium $\mathbf{1 . 5 ~ S}$ & $1.5 \mathrm{~mL}$ & $1.5 \mathrm{~mL}$ & $6 \mathrm{drops}$ \\
\hline Double strength: Medium $\mathbf{2 ~ S}$ & $2 \mathrm{~mL}$ & $2 \mathrm{~mL}$ & $8 \mathrm{drops}$ \\
\hline
\end{tabular}




\section{Monitoring and analysis of germination stages}

The materials in the test tubes were evaluated for seven weeks. In each week, one tube per treatment was removed from the growing room. Under stereoscopic microscopy, the tubes were opened and the spores were removed from the test tube containing the culture medium using forceps sterilized and transferred to a microscope slide.

To enable optimal observation of the characteristics and development of the spores under a light microscope, preparation was undertaken according to Wodehouse's (1935) method, following Luizi-Ponzo \& Melhem's (2006) modifications (use of gelatine glycerinated with dyes used in plant anatomy for spore observation). Slides were identified, dated and included in the collection of the Bryophyte Laboratory at the Universidade Federal de Juiz de Fora. Photomicrographs were obtained using a Canon PowerShot A620 camera coupled to a Zeiss Primo Star 12 V DC light microscope.

When observing the characteristics presented and the development of the spores, the diameter and number of cells of the globular protonema (DGP and NCGP), length and number of cells of the external protonema (LEP and NCEP) were analyzed and compared using the ZEN 2012 (Zeiss) program. The number of cells was obtained through a cell count on the face towards the viewer. For each parameter was established a sample of five repetitions. The sample sizes in each week were 25 measures.

\section{Statistical treatment}

The data of diameter and number of cells of the globular protonema (DGP and NCGP), length and number of cells of the external protonema (LEP and NCEP) were submitted to Shapiro-Wilk normality test and to a graphic evaluation. None of the parameters were normally distributed, showing $\mathrm{p}$ value $<0.05$ (DGP: $\mathrm{p}$ value $=2.779 \mathrm{e}^{-12}$; NCGP: pvalue $=$ 7.087e $\mathrm{e}^{-11}$; LEP: pvalue $=9.127 \mathrm{e}^{-13} ;$ NCEP: $\mathrm{p}$ value $=4.908 \mathrm{e}^{-}$ $\left.{ }^{10}\right)$. Graphic evaluation using boxplot methods and median were presented. Thus, a non-parametric test, Kruskal-Wallis test, was performed to determine if these parameters were different between treatments. Following, a posteriori test, Dunnest test, was applied for indentify the different treatment. The statistical analysis were developed in $\mathrm{R}$ ver. 3.3.1 (2016-06-21) (R Core Team 2016).

\section{Results}

\section{Germination stages and development}

The spores of Frullania ericoides are nonpolar and subspheroidal, with an intense green colour and a light brown wall; with average larger diameter of spores ranging around $40 \mu \mathrm{m}$. In the first week of the analysis, there was development of a globular and multicellular protonema enclosed in the spore wall that expanded without cracking, a typical endosporic germination (Fig. 1A-L, 2A-H). It was possible to observe cell division of the protonema cells. At certain points, the spore wall ruptured by developing an elongated chlorophyll cell with a hyaline wall (Figs. 1A-D, $2 \mathrm{~A}-\mathrm{C})$. We interpreted this as the initial development of an external protonema. During the second week there was an increase in diameter of the globular protonema and the external protonema continued elongating (Fig. 1C, D).

By the third week, the external and unicellular protonema developed into a multicellular protonema: flattened appearance, quadrate chlorophyll cells and inconspicuous walls. Morphologically, there are notable differences between $0.25 \mathrm{~S}, 0.5 \mathrm{~S}, 1 \mathrm{~S}$ and $1.5 \mathrm{~S}$, whereas in the $2 \mathrm{~S}$ treatment, the development of the external protonema was little (Figs. 1E, F, 2D, E).

At the third week, it was possible to observe the further development of the external protonema, which starts to develop in a fragile stem. In fourth week, primary leaves were observed along the outer protonema: spread from the middle region to the apex, alternately, slightly concave, chlorophyllous, with an entire margin and thick cell walls (Fig. 1F, G). This occurs in all treatments but in treatment $2 \mathrm{~S}$ (Fig. 2D-H). We also observed elongated cells that have broken the spore wall in new sites (Figs. 1E, H, 2E), but for unknown reasons did not develop into multicellular protonema. Possibly they can differentiate into rhizoids.

From the fifth week the external protonema continued differentiation into stem and leaves (Fig. 1I-L). Until the last week of observation (week 7), they showed slightly concave leaves, entire, not divided into segments like lobe and lobule (Fig. 1L); except for spores undergoing treatment 2S, which had a minimum investment in external protonema and great development of globular protonema (Fig. 2G, H).

\section{Statistical analysis of the effects of in vitro culture}

The boxplot graphics allow us to observe the distribution of data, its asymmetry and outliers (Fig. 3). The data of each parameter were plotted considering treatments and, likewise, Kruskal-Wallis test was performed. For diameter of globular protonema, treatment $2 \mathrm{~S}$ owns the most dispersed data, with some outliers and the greater median; in general, data were symmetric distributed. Kruskal-Wallis test show a $p=0.07252$, revealing that these data are not significantly different (Fig. 3A). In number of cells of globular protonema, as diameter of globular protonema, treatment $2 \mathrm{~S}$ has highlighted by dispersed data and greater median (Fig. 3B). The treatment $0.25 \mathrm{~S}$ has highlighted too by its outliers in distribution and the median next to treatment $2 S$ (Fig. 3B). Kruskal-Wallis test show a $p=0.004696$, revealing that the data conducted differently between treatments and are different. On the other hand, in length of external protonema and number of cells of external protonema, the 


\section{Spore germination, early development and some notes on the effects of in vitro culture medium on Frullania ericoides (Nees) Mont. (Frullaniaceae, Marchantiophyta]}


(D)
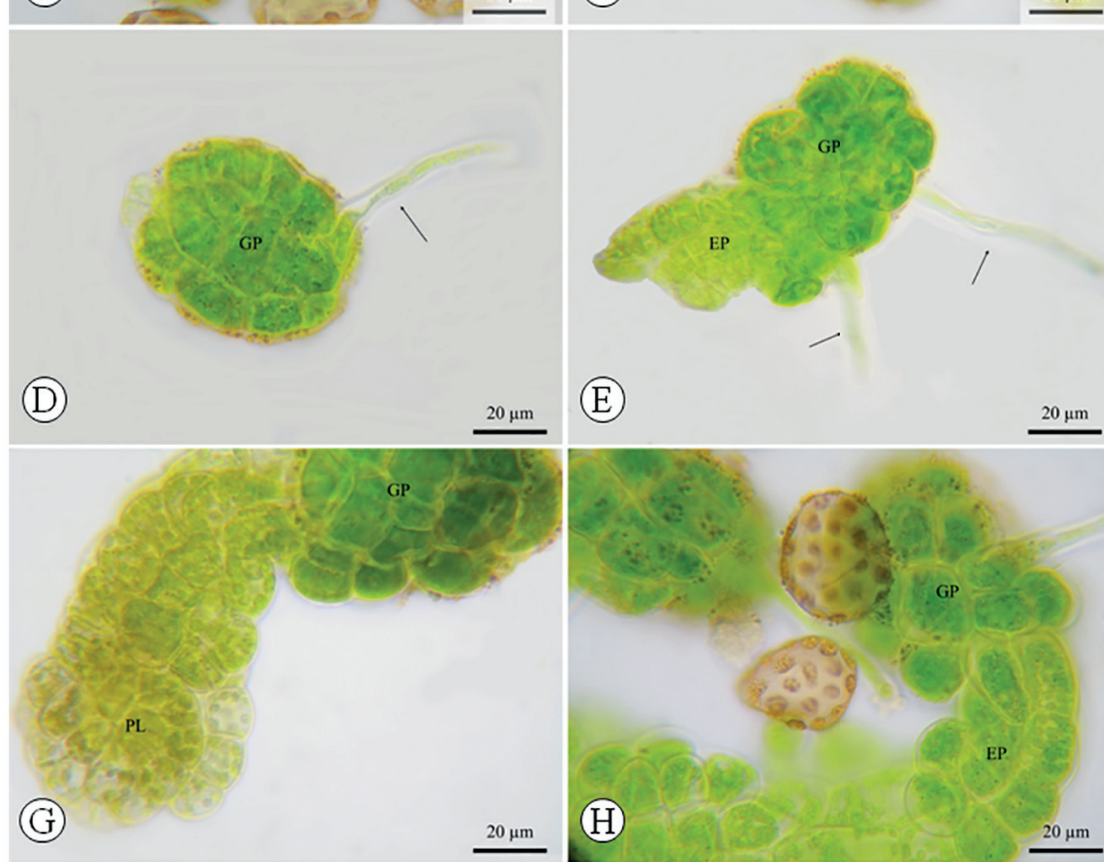

(E)

$20 \mu \mathrm{m}$

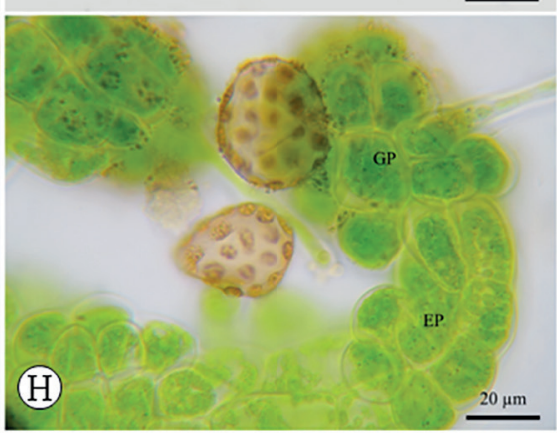

(F)

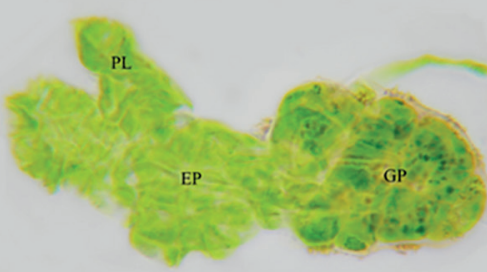

$20 \mu \mathrm{m}$
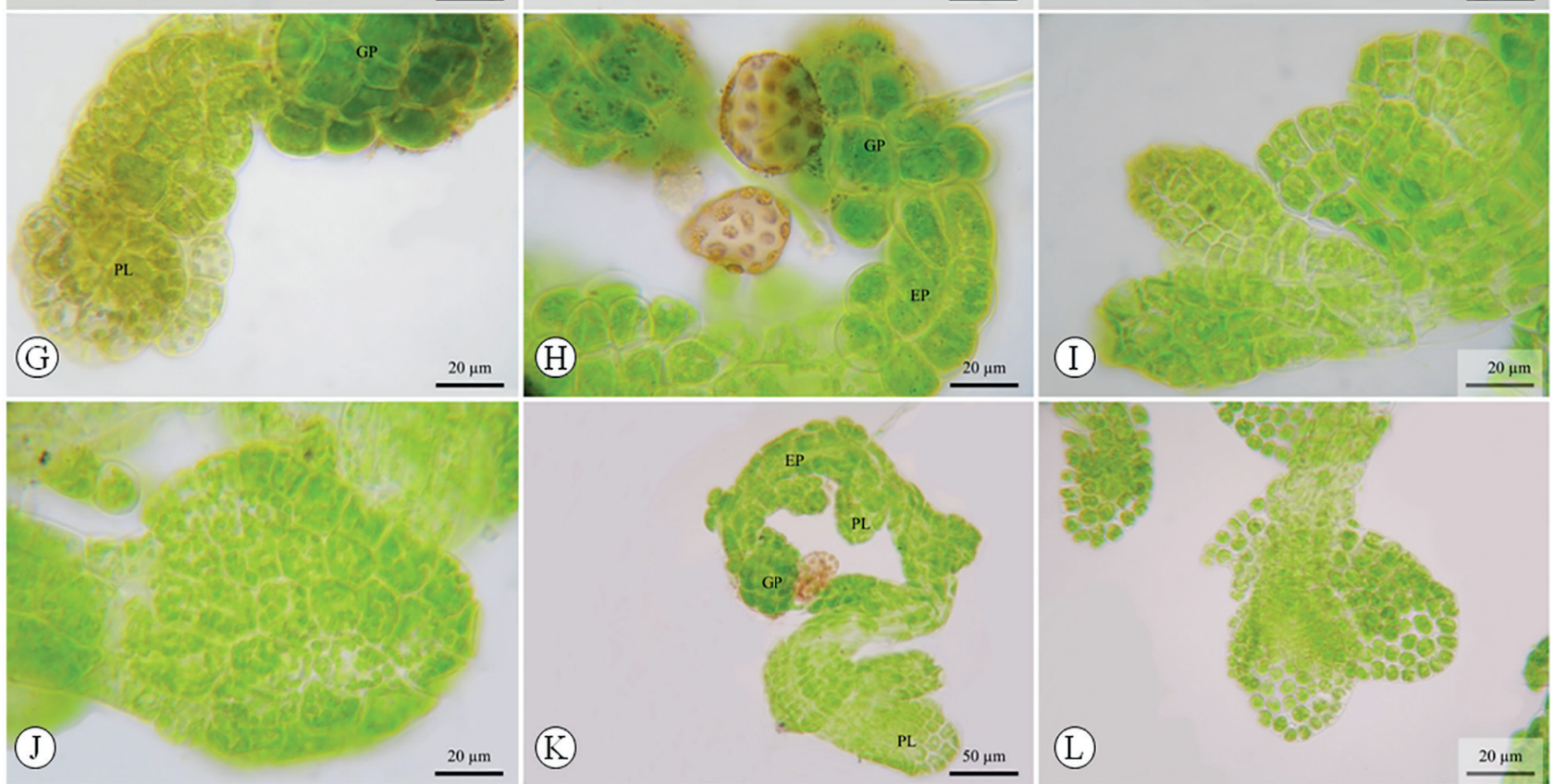

Figure 1. Photomicrographs of the development of globular protonema and external protonema during weeks of observation. A: First week, half strength; B,C: First week, full strength; D: Second week, half strength; E: Third weed, one and a half strength; F: Fourth week, one and a half strength; G: Fourth week, one-fourth strength; H: Fifth week, one-fourth strength; I: Primary leaves, Sixth week, half strength; J: Primary leaves, Sixth week, one-fourth strength; K: Seventh week, one and a half strength; L: Primary leaves, Seventh week, full strength. GP: Globular protonema; SW: Spore Wall; EP: External Protonema; PL: Primary Leaves; Arrow: unicellular external protonema.

most dispersed data was observed in treatment $0.5 \mathrm{~S}$ and treatment 0.25 S, respectively, and the greater median in diluted treatments. Number of cells of external protonema presented the most asymmetric data (Fig. 3C, D). KruskalWallis test demonstrates a $p=0.002781$ for length of external protonema and $p=0.4043$ for number of cells of external protonema.
The post hoc revealed that for length of external protonema and number of cells of external protonema, the $2 \mathrm{~S}$ treatment was the statistically different treatment from the others $(p<0.05)$ (Fig. 2B, C). Regarding number of cells of globular protonema, differences were found between: $0.25 \mathrm{~S}$ and $1 \mathrm{~S}$; and $2 \mathrm{~S}$ in relation to $0.5 \mathrm{~S}, 1 \mathrm{~S}$ and $1.5 \mathrm{~S}(p$ $<0.05$ ) (Fig. 2D). 
Juliana da Costa Silva-e-Costa, Andrea Pereira Luizi-Ponzo,

Cristiano Ferrara de Resende and Paulo Henrique Pereira Peixoto



Figure 2. Photomicrographs of the development of globular protonema and external protonema of double strength treatment through the time. A,B: First week; C: Second week; D: Third week; E: Fourth week; F: Fifth week; G: Sixth week; H: Seventh week. SW: Spore Wall; GP: Globular protonema; EP: External Protonema; Arrow: unicellular external protonema. 

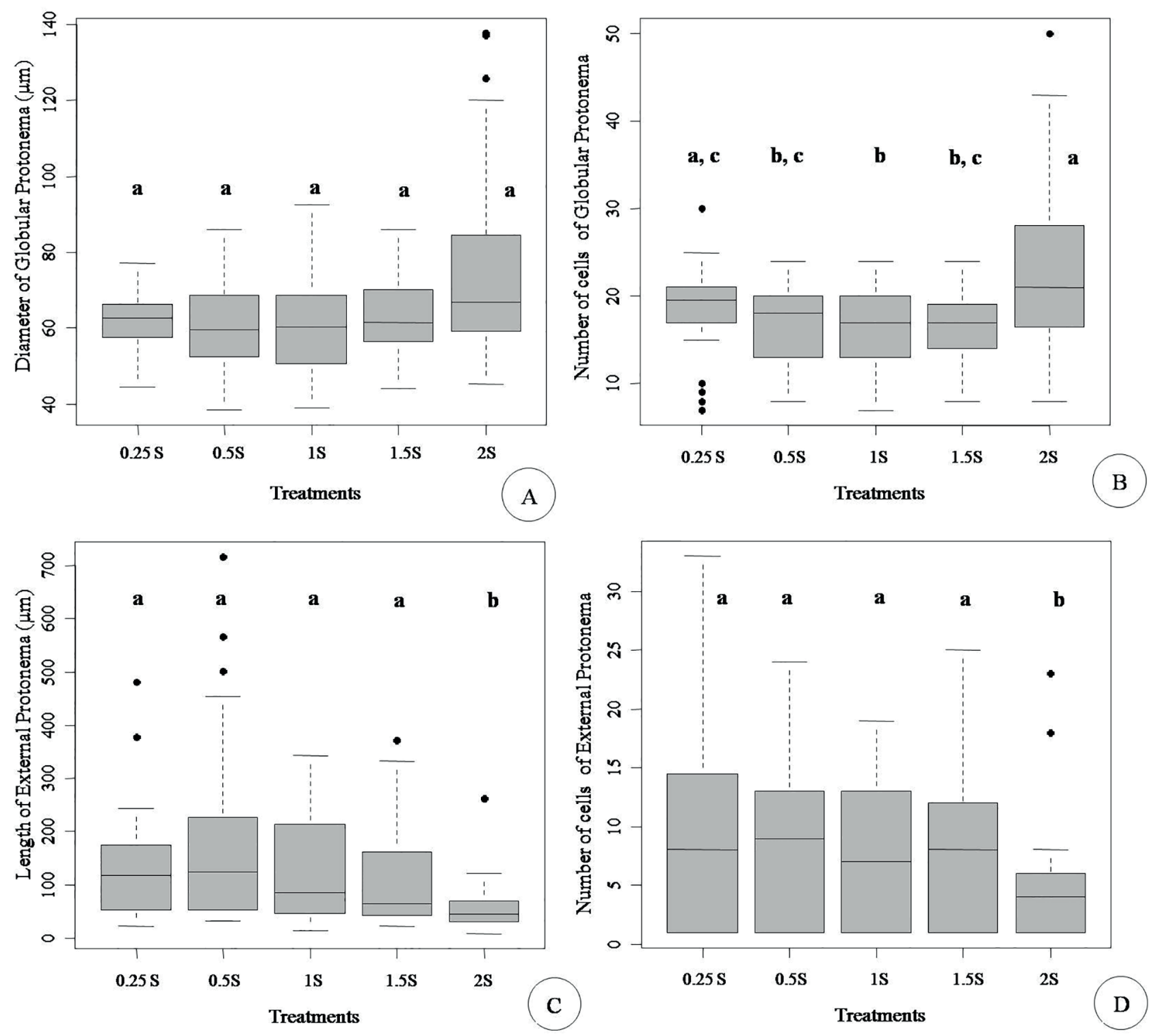

Figure 3. Boxplots representing parameters analyzed by treatments. A: Diameter of globular protonema by treatments; B: Number of cells of globular protonema by treatments; C: Length of external protonema; D: Number of cells of external protonema by treatments. Error bars above and below the box indicate the $90^{\text {th }}$ and $10^{\text {th }}$ percentiles, and dark circles represent the outliers. Different letters (a, b, c) represent statistical differences among treatments (Krukal -Wallis test, Dun test post hoc, $p<0.05$ ).

\section{Discussion}

The endosporic germination observed in all treatments to which the spores were subjected (independent of the concentration) and the sporeling morphology confirm the findings of Nehira (1983) and Bisang (1987), who also studied the genus Frullania. In his work, Nehira (1983) inoculated Frullania densiloba spores observing a globular protonema development of about 20 cells which developed within the spore wall, as in this study. It was also observed development of rhizoids and young leaves, in this present study. The time for the development of leaves was not specified by the author or descriptions of external protonema. Bisang (1987) studied Frullania tamarisci spores found the development of a globular protonema twice the initial spore diameter without breaking the spore wall and leafy development after three weeks. In our work, the appearance of primary leaves was later, after four weeks. These differences may be associated to growing conditions as well light and temperature of growing chamber in our studies.

Observing the development of protonema and sporeling over the weeks, we found that on $0.25 \mathrm{~S}, 0.5 \mathrm{~S}, 1 \mathrm{~S}$ and $1.5 \mathrm{~S}$ strength, occurred slight spore development considering of larger diameter cells and the number of globular protonema 
cells, but there was a boost in the development of the external protonema, presenting well-developed sporeling and with appropriate morphology, as well as the presence of leaves. In the higher medium strength (2S), the sporeling achieved higher values for the diameter and number of cells of the protonema, but not in development of external protonema and primary leaves.

Treatment $2 \mathrm{~S}$ stands out from the other treatments for the larger development of the globular protonema, but it was not successful in attaining appropriate development of the sporeling. According to Basile (1975), the species subjected to in vitro culture may develop differently in response to macronutrients which are used in the culture media. Alcade et al. (1996), in a study of four species of the genus Bartramia Hedw, found that the same species presented different types of protonema in response to different nitrogen sources in the medium and also the temperature and photoperiod to which it was subjected. Therefore, the $100 \%$ increase in strength of the medium caused an uncontrolled proliferation of cells in the treated spores and resulted in an increase in the diameter of the protonema, but inhibited the development of mature gametophyte structures compared to lower concentrations; same results were present here.

Besides having a nutritive effect, solutions of inorganic salts and sugars, which compose tissue culture media, influence plant cell growth through their osmotic properties (George et al. 2008). Inorganic salts, as those used in this study $\left(\mathrm{Ca}\left(\mathrm{NO}_{3}\right)_{2}\right)$, can change the water potential of their solutions. Thereby, the strength of the culture medium has a direct effect on osmotic potential to which the tissues, and here, spores are exposed.

Udar \& Srivastava (1970) studied the sporeling development of Preissia quadrata, a thalloid liverwort, using two different concentration of Knop's nutrient solution (half-strength and full-strength), but did not evaluate the development in response to the strength of the medium, focusing rather on the description of sporeling development. In their work, the spores germinated in a period of four to seven days, depending of the time between collection and inoculation. In the present study, in first week there were development and germination. Sahu \& Asthana (2013), studing the moss Anomobryum filiforme var. concinnatum, used four culture media, including solution knop full strength and half strength. In general, those spores which have been subjected to treatment Knop full strength showed the development of germination characteristics delayed compared to treatment half strength.

Regarding results of statistics treatments, the parameter diameter of globular protonema were statistically similar between treatments media probably because this is a feature that is lower affected by concentrations of culture media. The parameter number of cells of globular protonema, in turn, showed a complex arrangement of statistic differences. In this case, surprisingly, the weakest strength was more similar to strongest strength and the half-strength, full strength and one and a half strength were more similar each other. For the parameters analyzed in external protonema, double strength treatment showed the most different morphology, without satisfactory growth of this phase of sporeling.

\section{Conclusions}

Frullania ericoides spores exhibited endosporic germination, development, in a first stage, a globular protonema and then an external protonema. This phases of sporeling is remarkable for epiphytic bryophytes species, specially leafy liverworts. After three weeks of experiment, the external protonema has developed strongly concave primary leaves, remarkable featuring of this species. The experiments of in vitro culture performed in our work demonstrated that the development and establishment of sporeling (mainly external protonema) in F. ericoides is suitable in different concentrations of Knop's solution; and confirm the potential of tissue culture techniques for bryophyte spore studies.

\section{Acknowledgements}

We thank Christiane Valle and Lyderson Viccini, for support; Daniel Pimenta, for allowing the sample collection at JB-UFJF; Simone Cardoso, for statistical analyses assistance; Irene Bisang and Nicholas McLetchie, for discussions about in vitro culture of the Frullania genus; and FAPEMIG (Fundação de Amparo à Pesquisa do Estado de Minas Gerais) for supporting researches at Bryophytes Laboratory/UFJF. This work was conducted during the validity of a scholarship to first author, supported by CAPES at the Post graduate Program of Ecology/UFJF.

\section{References}

Alcade M, Abella L, Estébanez B, Ron E. 1996. Protonemal development under different culture conditions in Bartramia Hedw. (Musci). Journal of Hattori Botanical Laboratory 79: 107-114

Alfayate C, Ron E, Estébanez B, Pérez - Batista MA. 2013. Mature spores of four pleurocarpous mosses in the Canary islands: ultrastructure and early germination stages. The Bryologist 116: 97-112

Awasthi V, Virendra N, Asthana AK. 2012. In vitro regeneration and micropropagation of some liverworts from vegetative ex plants. National Academy Science Letters 35: 7-12.

Basile DV. 1975. A Comparision of Some Macronutrient Media Used to Culture Bryophytes. The Bryologist 78: 403-413.

Berghen CV. 1976. Frullaniaceae (Hepaticae) africanae. Bulletin du Jardin Botanique National de Belgique 46: 1-220.

Bisang I. 1987. The sporeling development in Frullania tamarisci (L.) Dum. Journal of Bryology 14: 761-763

Brown RC, Lemmon BE .1988. Sporogenesis in Bryophytes. Advances in Bryology 3: 159-223.

Chen Y-Y, Lou YX, Guo SL, Cao T. 2009. Successful tissue culture of the medicinal moss Rhodobryum giganteum and the factors influencing proliferation of its protonema. Annales Botanici Fennici 46: 516-524. 


\section{Spore germination, early development and some notes on the effects of in vitro culture medium on Frullania ericoides (Nees) Mont. (Frullaniaceae, Marchantiophyta]}

Crandall-Stotler B, Stotler RE, Long DG .2009. Morphology and Classification of the Marchantiophyta. In: Goffinet B, Shaw JA. (eds.) Bryophyte Biology, 2nd. edn. Cambridge, New York, Cambridge University Prees. p. 1-54.

Duckett JG, Burch J, Fletcher PW, et al. 2004. In vitro cultivation of bryophytes: a review of practicalities, problems, progress and promise. Jounal of Bryology 26: 3-20

Erdtman G. 1957. Pollen and spore morphology/plant taxonomy - Gymnospermae, Pteridophyta, Bryophyta (Illustrations). An introduction to palynology II. Stockholm, Almqvist \& Wiksell/Gebers Förlag AB.

Fulford M. 1956. The young stages of leafy Hepaticae: a résumé. Phytomorphology 6: 199-235.

George EF, Hall MA, Klerk G-J. 2008. Plant propagation by tissue culture. Volume 1. The background. 3rd.edn. Dordrecht, Springer.

Glime JM. 2007. Bryophyte Ecology. Volume 1. Physiological ecology. Houghton, Ebook sponsored by Michigan Technological University and the International Association of Bryologists. www.bryoecol.mtu.edu.

Glime JM. 2015. Ecophysiology of development: spore germination. In: Glime JM. (ed.) Bryophyte Ecology. Vol. 1. Physiological Ecology. Houghton, Ebook sponsored by Michigan Technological University and the International Association of Bryologists. p. 5-2-1 - 5-2-28.

Goffinet B, Buck WR, Shaw AJ. 2009. Bryophyte Biology. Cambridge, New York, Cambridge University Press.

Gradstein SR, Churchill SP, Salazar-Allen N. 2001. Guide to the Bryophytes of Tropical America. New York, Memoirs of the New York Botanical Garden.

Gradstein SR, Costa DP. 2003. The Hepaticae and Anthocerotae of Brazil. New York, Memoirs of the New York Botanical Garden.

Gradstein SR, Pócs T. 1989. Bryophytes. In: Lieth H, Werger MJA. (eds.) Tropical Rain Forest Ecosystems. Amsterdam, Elsevier Science Publischers. p. 311-325.

Gupta A, Udar R. 1986. Palyno-taxonomy of selected Indian Liverworts. Stuttgart, Quindago.

Heckman CA. 1970. Spore Wall Structure in the Jungermanniales. Grana 10: 109-119.

Hentschel J, Konrat MJ, Pócs T, et al. 2009. Molecular insights into phylogeny and subgeneric classification of Frullania Raddi (Frullaniaceae, Porellales). Molecular Phylogenetics and Evolution 52: $142-156$

Horikawa Y, Nehira K. 1960. The spore germination in Bazzania pompeana (lac.) Mitt. Hikobia 2: 109-110.

Inoue H. 1960. Studies in spore germination and the earlier stages of gametophyte development in the Marchantiales. Journal of Hattori Botanical Laboratory 23: 148-191.

Konrat M, Lange P, Greif M, Strozier L, Hentschel J, Heinrichs J. 2012. Frullania knightbridgei, a new liverwort (Frullaniaceae, Marchantiophyta) species from the deep south of Aotearoa-New Zealand based on an integrated evidence-based approach. PhytoKeys 8: 13-36.

Krishnan R, Murugan K. 2014. Axenic culture of bryophytes: A case study of liverwort Marchantia linearis Lehm. \& Lindenb. Indian Journal of Biotechnology. 13: 131-135.

Lemos-Michel E. 2001. Hepáticas Epífitas sobre o pinheiro-brasileiro no Rio Grande do Sul. Porto Alegre, Editora da Universidade Federal do Rio Grande Do Sul.

Longton RE. 2006. Reproductive ecology of bryophytes: what does it tell us about the significance of sexual reproduction? Lindenbergia 31: 16-23.

Longton RE, Schuster RM. 1983. Reproductive Biology. In: Schuster RM. (ed.) New manual of Bryology. 1st. edn. Nichinan, The Hattori Botanical Laboratory. p. 386-462.

Luizi-Ponzo AP, Melhem TS. 2006. Spore morphology and ultrastructure of the tropical moss Helicophyllum torquatum (Hook.) Brid. (Helicophyllaceae) in relation to systematics and evolution. Cryptogamie Bryologie 27: 413-420.

Maciel-Silva AS, Pôrto KC, Simabukuro EA. 2009a. Effect of light and water availability on spore germination and protonemal growth of the Neotropical moss Thamniopsis incurva (Pilotrichaceae). Cryptogamie, Bryologie 30: 243 -245.
Maciel-Silva AS, Simabukuro EA, Pôrto KC. 2009b. Effect of water availability on spore germination of the spore moss Octoblepharum albidum from Brazilian Atlantic Forest. Journal of Bryology 31: 169173.

McLetchie DN. 2001. Sex-Specific Germination Response in the Liverwort Sphaerocarpos texanus (Sphaerocarpaceae). The Bryologist 104: 69-71. Mogensen GS. 1978. Spore development and germination in Cinclidium (Mniaceae, Bryophyta), with special reference to spore mortality and false anisospory. Canadian Journal of Botany 56: 1032-1060.

Mogensen GS. 1983. The spore. In: Shuster RM. (ed.) New manual of Bryology. 1st. edn. Nichinan, The Hattori Botanical Laboratory. p. 324-342.

Nehira K. 1966. Sporelings in the Jungermanniales. Journal of Science of the Hiroshima University 2: 1-49.

Nehira K. 1983. Spore germination, protonema development and sporeling development. In: Shuster RM. (ed.) New manual of Bryology. 1st. edn. Nichinan, The Hattori Botanical Laboratory. p. 343-385

Nehira K. 1987. Some ecological correlations of spore germination patterns in liverworts. The Bryologist 90: 405-408.

Nehira K. 1988. Germination and protonemata. In: Glime JM. (ed.) Methods in Bryology. 1st. edn. Nichinan, The Hattori Botanical Laboratory. p. 113-117

Neidhart HB. 1979. Comparative studies of sporogenesis in bryophytes. In: Clarke GCS, Duckett JG. (eds.) Bryophyte Systematics. Vol 14. London, Academic Press. p. 251-280.

Olesen P, Mogensen GS. 1978. Ultrastructure, histochemistry and notes on germination stages of spores in selected mosses. The Bryologist 81: 493-516

Oliveira-e-Silva M IMN, Yano O. 2000. Anthocerotophyta e Hepatophyta de Mangaratiba e Angra dos Reis, Rio de Janeiro, Brasil. Boletim do Instituto de Botânica de São Paulo 14: 1-137.

Paiva LA, Silva JC, Passarella MA, Luizi-Ponzo AP. 2015. Briófitas de um fragmento florestal urbano de Minas Gerais (Brasil). Pesquisas, Botânica 67: 181-199.

Peralta DF. 2015. Frullaniaceae In: Forzza RC. (ed.) Lista de Espécies da Flora do Brasil. Rio de Janeiro, Jardim Botânico do Rio de Janeiro. http://reflora.jbrj.gov.br/jabot/floradobrasil/FB97292.

R Development Core Team. 2016. R: A Language and Environment for Statistical Computing. Vienna, The R Foundation for Statistical Computing. ISBN: 3-900051-07-0. http://www.R-project.org/.

Sahu V, Asthana, AK. 2013. An observation on growth response of Anomobryum filiforme var. concinnatum (Spruce) Aman. (Bryaceae) in different culture media. National Academy Science Letters 36: 587-589.

Schofield WB .1985. Introduction of Bryology. New York, Macmillan Publishing Company.

Schuster RM. 1966. The Hepaticae and Anthocerotae of North America East of Hundreth Meridian.Vol. 1. New York, Columbia University Press.

Stotler RE .1970. The genus Frullania subgenus Frullania in Latin America. Nova Hedwigia 18: 397-555

Udar R, Srivastava SC. 1970. Sporeling Development in Pressia quadrata. Phyton (Austria) 14: 165-173.

Uribe JM. 2008. Monografía de Frullania subgénero Meteoriopsis (Frullaniaceae, Marchantiophyta). Caldasia 30: 49-94.

Uribe JM, Gradstein SR. 2003. Type studies on Frullania subgenus Meteoriopsis (Hepaticae). I. The lectotypification of the genus Frullania, F. subgen. Thyopsiella and F. subgen. Meteoriopsis, and some species transferred from subgen. Meteoriopsis to subgen. Thyopsiella. Cryptogamie, Bryologie 24: 193-207

Vallane N. 1966. The germination phases of moss spores and their control by light. Annales Botanici Fennici 3: 1-60.

Vallane N. 1971. The effects of prolonged darknees and light on the fine structure of Ceratodon purpureus. Canadian Journal of Botany 49: 547-554

Vanderpoorten A, Goffinet B. 2009. Introduction to bryophyte biology. Cambridge, Cambridge University Press.

Wiklund K, Rydin H. 2004. Ecophysiological constraints on spore establishment in bryophytes. Functional Ecology 18: 907-913.

Wodehouse RP. 1935. Pollen Grains. Their structure, identification and significance in science and medicine. New York, McGraw-Hill Book Company. 
Juliana da Costa Silva-e-Costa, Andrea Pereira Luizi-Ponzo,

Cristiano Ferrara de Resende and Paulo Henrique Pereira Peixoto

Wu YJ, Yu J, Cao T. 2008. Observation of spore morphology and wall structure of eigth species of Frullania (Frullaniaceae; Hepaticae) by SEm and TEM. Journal of Wuhan Botanical Research 26: 337-342.

Yano O. 1989. Briófitas. In: Fidalgo O, Bononi VLR. (eds.) Técnicas de coleta, preservação e herborização de material botânico. São Paulo, Instituto de Botânica, Série Documentos. p. 27-30.

Yano O, Peralta DF. 2008. Flora do estado de Goiás e Tocantins. Criptógamos: antóceros (Anthocerotophyta) e hepáticas (Marchantiophyta). Goiânia, Universidade Federal de Goiás.

Yuzawa Y. 1991. A monograph of subg. Chonanthelia of gen Frullania (Hepaticae) of the world. Journal of Hattori Botanical Laboratory 57: 391-403.
Zanten BO, Pócs T. 1981. Distribution and dispersal of bryophytes. Advances in Bryology 1: 479.

Zhang YL, WU PC. 2006. Spore morphology of Chinese bryophytes. Qingdao, Qingdao Publishing House.

Zhao DP, Bai XL, Wang LH. 2011. Observations of spore morphology of some hepatics species (Marchantiophyta) in China. Arctoa 20: 205-210.

Zhao J-C, Huang S-L, Min L, et al. 2004. A study on characteristics of spore germination and protonemal development in Lindbergia brachyptera. Arctoa 13: 223:228. 